\title{
INCONSTITUCIONALIDADE SUPREMA? UMA ANÁLISE ACERCA DA (IN)CONSTITUCIONALIDADE DA DECISÃO MONOCRÁTICA PROFERIDA NA ADPF 7OI/MG E POSSÍVEIS REFLEXOS EM UM CENÁRIO DE PANDEMIA
}

\author{
Luiz Carlos Santos Junior ${ }^{1}$
}

RESUMO: Conquanto o Supremo Tribunal Constitucional - STF tenha o papel de guardião da Constituição, verifica-se cada vez mais a ocorrência de decisões monocráticas que por vezes são reformadas pelo Plenário, e, que, possivelmente, estariam eivadas de inconstitucionalidade, já que substituídas por outro entendimento considerado mais adequado ao ordenamento jurídico constitucional. Outrossim, embora o Plenário do STF não esteja vinculado aos seus próprios precedentes, eis que possuem o papel de revisá-los, a mesma conclusão não se pode aferir quanto à imprescindibilidade de observância dos precedentes por parte dos ministros da Corte ao proferirem decisões monocráticas. Nesse sentido, busca o presente artigo analisar aspectos da decisão monocrática proferida na ADPF 7oI/MG, quanto a possível existência de inconstitucionalidade e consequente corresponsabilização à luz da tese fixada em controle concentrado de constitucionalidade da MP no $966 / 2020$ e a necessidade de observância dos precedentes vinculantes do STF.

Palavras-Chave: Decisões monocráticas STF. Inconstitucionalidade. Precedentes Vinculantes. Pandemia. Responsabilização.

ABSTRACT: Although the Brazilian Supreme Court - STF has the role of guardian of the Constitution, monocratic decisions are occurring more and more, which are sometimes reformed by the Plenary, and which, possibly, would be riddled with unconstitutionality, since replaced by another one, understanding considered more appropriate to the constitutional legal system. Furthermore, although the STF Plenary is not linked to its own precedents, as they have the role of reviewing them, the same conclusion cannot be drawn regarding the indispensability of the Court's ministers to observe the precedents when making monocratic decisions. In this sense, this article seeks to analyze aspects of the monocratic decision handed down in $\mathrm{ADPF}$ 70I/MG, regarding the possible existence of unconstitutionality and

\footnotetext{
I Advogado, Mestrando em Direitos Sociais e Processos Reivindicatórios, Especialista em Civil e Processo Civil e Trabalho e Processo do Trabalho. E-mail: lcsj.adv@gmail.com.
} 
consequent co-responsibility in light of the thesis established in concentrated control of constitutionality of MP $n^{\circ} 966 / 2020$ and the need for compliance with binding precedents of the STF.

Keywords: Monocratic decisions STF. Unconstitutionality. Binding precedents. Pandemic. Responsibility.

\section{INTRODUÇÃO}

Em tempos de pandemia e com a crescente judicialização dos conflitos entre os poderes constituídos e entes federados acerca das suas respectivas competências, insofismável a digressão pela atuação do Poder Judiciário diante deste cenário, porquanto como protetor dos direitos fundamentais, no caso deste artigo ver-se-á em especial o direito à saúde, faz-se necessário perquirir se esse vem exercendo a jurisdição constitucional à luz da própria Constituição Federal.

Tal análise demonstra importância mormente pelo elevado número de decisões monocráticas proferidas em $2020^{2}$, as quais representam $82 \%$ das decisões proferidas pelo STF, quantificadas em 8I.16I do total de 99.0oo decisões, restando apenas 18.208 decisões colegiadas.

Enquanto decisões monocráticas, estas estão sujeitas ao crivo do Plenário do STF, o qual, enquanto Corte Constitucional, é responsável por apreciar, em última análise, a constitucionalidade da decisão, não sendo rara as vezes em que uma decisão monocrática possa vir a ser invalidada, o que se afigura como um oxímoro, tendo em vista a probabilidade do próprio guardião da Constituição, por meio de seus membros, exararem decisões inconstitucionais.

Do exposto, partir-se-á da premissa da plausibilidade de decisões monocráticas inconstitucionais no âmbito do STF, analisando a decisão proferida no seio da ADPF 7ol/MG, a fim de avaliar possíveis inconstitucionalidades e por consequência, concebíveis corresponsabilização nos termos propostos pela tese fixada no controle de constitucionalidade da MP 966/2020.

\footnotetext{
${ }^{2}$ http://portal.stf.jus.br/noticias/verNoticiaDetalhe.asp?idConteudo $=457782 \&$ ori $=\mathrm{I}$
} 


\section{ASPECTOS CONSTITUCIONAIS DO PAPEL DO SUPREMO TRIBUNAL FEDERAL}

\section{I. Da Legitimidade do Supremo Tribunal Federal enquanto Guardião da Constituição}

Indiscutível a legitimidade do Supremo Tribunal Federal enquanto Guardião da Constituição, em que pese algumas vezes sejam questionadas se a sua forma de composição e atuação se encontram em consonância com princípio da democracia, por não ser os seus representantes escolhidos em processo democrático direto que prestigie o voto popular, tal qual os membros dos poderes legislativos e executivo ${ }^{34}$.

Tal questionamento tem sentido, e, essa argumentação já fora explorada pelo jurista Carl Schmitt (2007, págs. I76-177), em sua obra o Guardião da Constituição:
Todavia, um Tribunal exclusivamente com juristas funcionários de carreira representaria afronta ao princípio democrático, verificando-se a criação de uma segunda câmara (legislativa), porquanto o exame judicial constitucional estaria concentrado nas mãos de funcionários inamovíveis e independentes, de uma configurando-se em uma instância de alta política dotada de poderes legislativos constitucionais. (...) do ponto de vista democrático, seria praticamente impossível transferir tais funções a uma aristocracia da tog $a^{5}$.

Contudo, não é correto afirmar que a configuração com a qual o Supremo Tribunal Federal é formado afronte de alguma forma o princípio democrático, pois a Constituição prevê a participação dos poderes executivos e legislativos no processo de escolha dos membros da Corte, privilegiando dessa forma, a participação popular por meio dos seus representantes eleitos.

Neste sentido, Bobbio (2009, pág. 30) refere-se à construção de uma definição mínima de democracia como "um conjunto de regras (primárias ou

\footnotetext{
${ }^{3}$ As decisões judiciais devem ser subordinadas à legislação, pois a sociedade deve ser governada por representantes eleitos e se o juiz criar direito após o caso concreto, a parte perdedora estará sendo julgada por um fundamento que não existia quando o fato jurídico aconteceu. (DWORKIN, 2002, p. 132)

${ }^{4}$ Para Norberto Bobbio (20oo, p. 380): “ [...] na democracia moderna, o soberano não é o povo, mas são todos os cidadãos.”. Dessa maneira, os cidadãos detêm o poder de construir uma sociedade, justa, livre e igualitária.

${ }^{5}$ Grifo do autor.
} 
fundamentais) que estabelecem quem está autorizado a tomar as decisões coletivas e com quais procedimentos".

Assim, para que uma decisão adotada por alguns indivíduos seja aceita como decisão coletiva é imprescindível que ela seja tomada com base em regras e procedimentos. Mas isso não basta, porque, além de garantir o direito de participação a um elevado número de cidadãos e de defender a existência de regras e procedimentos, ele acrescenta uma terceira condição, "é preciso que aqueles que são chamados a decidir ou eleger os que deverão decidir sejam colocados diante de alternativas reais e postos em condição de escolher entre uma e outra" (BOBBIO, 2009, pág. 32).

Corrobora o entendimento acerca do caráter democrático do Supremo Tribunal Federal, o fato de este ser uma instância colegiada, o que reforça a sua independência e imparcialidade para atuar como Guardião da Constituição, protegendo-o de pressões externas, e, de certo modo, estabelecendo um sistema de "freios e contrapesos" em si próprio, eis que a tendência de pluralidade de visões tende a neutralizar posições extremas e por demais subjetivas, culminando em debates mais objetivos, bem fundamentados e sensatos.

Jurgen Habermas, citado por COHENDET (2006, pág. 713), demonstrou que, de uma maneira geral, a deliberação traduz-se em um conceito processual de democracia. Montesquieu, por sua vez, afirma que se a colegialidade é inerente à nossa tradição jurídica é porque, fundamentalmente, consideramos muito melhor uma decisão tomada por uma deliberação do que pela decisão de um único.

Do exposto, convicto de que o STF se coaduna ao princípio democrático, não havendo dúvidas quanto a sua legitimidade para a funcionar enquanto Guardião da Constituição, é mister refletir se de igual modo, a atuação singular dos seus membros, ao proferir decisões monocráticas sem embasamento anterior da Corte apto a fundamentar que estes estão decidindo em nome do colegiado, também possuem o condão de ser consideradas como pronunciamentos do Guardião da Constituição? 
Ademais, a abusiva e reiterada utilização de decisões monocráticas pode vir a configurar violação ao princípio da colegialidade e consequentemente ao princípio democrático, podendo ocasionar a deslegitimação do STF enquanto Guardião da Constituição?

É nessa toada que COHENDET (2006, pág. 736) afirma que a Separação dos Poderes não seria efetiva se a colegialidade não fosse respeitada. O princípio da colegialidade seria o corolário necessário de independência e imparcialidade de justiça, princípio, inequivocamente, de valor constitucional e que reafirma o caráter democrático de um legítimo Guardião da Constituição.

Estas são questões espinhosas que pretendemos abordar e apresentar a nossa visão no decorrer do artigo.

\subsection{Da necessidade de estabelecimento de limites à atuação monocrática dos membros do STF}

Com o advento da Constituição de 1988, após a redemocratização do País, os poderes da República permeavam os desafios da readaptação ao regime democrático, e o Supremo Tribunal Federal, ainda composto por membros oriundos do regime militar, possuía atuação mais conversadora, tímida, guiando-se pelo positivismo jurídico que permanecia vigente, o qual se pautava em separar o direito de outros ramos do conhecimento, como filosofia, psicologia, política, economia, com o fito de garantir objetividade às decisões judiciais, tendo o juiz como uma mero tradutor e aplicador das leis. Contudo, esse contexto mudou. De acordo com Barroso (2015, pág. 27):

\footnotetext{
no início dos anos 200o, essa disfunção foi sendo progressivamente superada e o STF foi se tornando, verdadeiramente, um intérprete da Constituição. A partir daí, houve demanda por maior sofisticação teórica na interpretação constitucional, superadora da visão tradicional de que se tratava apenas de mais um caso de interpretação jurídica, a ser feita com base nos elementos gramatical, histórico, sistemático e teleológico. Foi o início da superação do positivismo normativista e de sua crença de que a decisão judicial é um ato de escolha política.
}

A partir daí, surge o que chamamos de pós-positivismo, operando-se uma inovação quanto à hierarquia das normas anteriormente concebida, as normas são 
divididas entre regras (positivadas) e princípios, conferindo-se a estes últimos força normativa, dotados de superioridade quanto aos primeiros. A Constituição Federal passa a ser a centralidade de todo o ordenamento jurídico, integrando todas as demais normas aos seus princípios fundamentais, funcionando como parâmetro interpretativo.

Nesse sentido, amplia-se o papel do judiciário como um todo, sobretudo do $\mathrm{STF}$, uma vez que todas as normas estão sendo interpretadas à luz dos princípios fundamentais constitucionais, o que permite maior discricionariedade interpretativa, já que os princípios são dotados de maior abstração e possibilitam uma valoração mais subjetiva a critério do julgador, dando ensejo ao que se chama ativismo judicial.

Não há consenso na doutrina, havendo conceituações mais favoráveis, outras menos, levando-se em consideração os efeitos positivos e negativos decorrentes do ativismo judicial. No entanto, colaciona-se abaixo um entendimento considerado moderado, de modo que Thamy Pogrebinschi (200o, p. 2), considera ativista o juiz que:

a) use o seu poder de forma a rever e contestar decisões dos demais poderes do estado; b) promova, através de suas decisões, políticas públicas; c) não considere os princípios da coerência do direito e da segurança jurídica como limites à sua atividade.

Acrescenta ainda a autora:

Não queremos sustentar que os três critérios acima devam ser preenchidos simultaneamente para que se identifique um caso de ativismo. Um juiz pode ser considerado ativista pelo exercício em graus diferenciados de quaisquer das atitudes acima descritas.

Porém, a negação de qualquer destas atitudes implica, segundo nossa definição, que ele não seja considerado um ativista. Isto é, um juiz que se recuse a exercer seu poder de pelo menos uma das formas acima, não será considerado, neste artigo, um ativista.

Desse modo, perante a sociedade, não se nega a importância de certo grau de ativismo judicial com vistas à garantia dos direitos fundamentais, porquanto vivemos em uma situação generalizada de violações de direitos em virtude de omissões e inconsequências de agentes públicos dos poderes Executivo e Legislativo, 
contudo, relevante também é buscar limites para a atuação do judiciário, porquanto a regra é a irresponsabilidade estatal pelas decisões judiciais.

Assim, admoesta Marinoni (2013, pág. 64):

[...] não há poder que não tenha responsabilidade pelas suas decisões. Porém, é pouco plausível que alguém possa justificar a sua responsabilidade quando decide casos iguais de forma desigual" (...) "tratar da mesma forma casos similares é algo fundamental para a estabilidade do Poder.

Dessa forma, constata-se a necessidade de criar mecanismos de limitação à atuação do STF, particularmente no que tange ao exercício da jurisdição constitucional de forma singular, por meio de decisões monocráticas, pois se constitui em um elevado poder nas mãos de agentes públicos que dificilmente serão responsabilizados por eventuais danos ocasionados à sociedade, embora atualmente funcione muitas vezes como gestor público, como pretende-se demonstrar no presente artigo, implementando diretamente, ou mesmo restringindo, a adoção das medidas necessárias ao combate à pandemia.

Inconteste o desconforto dos poderes Executivo e Legislativo e a ânsia em equalizar as forças, arrefecendo-se o ativismo judicial de decisões monocráticas do STF, primando pela independência e harmonia dos Poderes, tanto que tramita no Senado Federal a Proposta de Emenda à Constituição - PEC no 8/2021 6 , que dispõe sobre a altera da Constituição Federal para dispor sobre os pedidos de vista, declaração de inconstitucionalidade e concessão de medidas cautelares nos tribunais.

Nesse contexto, revela-se importante a adoção de precedentes judiciais, sobretudo os vinculantes, devendo estes serem enxergados não como uma limitação negativa ao poder decisório ou violação à independência de convencimento do juiz, mas como uma limitação positiva no sentido de garantir ao jurisdicionado uma jurisprudência íntegra e coerente, além de reforçar o equilíbrio entre os Poderes, privilegiando os princípios da democracia e separação dos poderes, e, no caso do STF,

\footnotetext{
${ }^{6}$ Trecho da justificativa da PEC: "É chegada a hora de rediscutir tema de grande importância para o equilíbrio das instituições no Brasil. Não se pode mais conviver com um modelo em que decisões judiciais individuais e precárias determinem o futuro de questões de grande relevância nacional."
} 
o princípio da colegialidade, respeitado quando os seus próprios membros observam os precedentes fixados pelo Plenário.

\section{DO CARÁTER VINCULANTE DA DECISÃO PROFERIDA NA ADI 642I $\mathrm{MC} / \mathrm{DF}$}

Preliminarmente, antes de proceder a análise da decisão monocrática proferida no $\mathrm{ADPF}$ 70I/MG, mister responder um possível questionamento que poderá surgir: As teses fixadas pelo STF no controle concentrado de constitucionalidade de medidas provisórias que perdem a validade continuam sendo precedentes vinculantes?

Essa indagação é justificada pelo fato da Medida Provisória no 966/2020, que dispôs sobre a responsabilização de agentes públicos por ação e omissão em atos relacionados com a pandemia da covid-I9, haver perdido a sua validade em Io/o9/2020, por não ter sido votada no Congresso Nacional.

Todavia, anteriormente a perda de sua validade, a referida MP fora objeto de controle de constitucionalidade pelo Supremo Tribunal Federal, por meio da ADI 642I $\mathrm{MC} / \mathrm{DF}^{7}$, o qual decidiu pela sua constitucionalidade, realizando uma intepretação conforme a Constituição, fixando as seguintes teses:

I. Configura erro grosseiro o ato administrativo que ensejar violação ao direito à vida, à saúde, ao meio ambiente equilibrado ou impactos adversos à economia, por inobservância: i) de normas e critérios científicos e técnicos; ou ii) dos princípios constitucionais da precaução e da prevenção. 2. A autoridade a quem compete decidir deve exigir que as opiniões técnicas em que baseará sua decisão tratem expressamente: i) das normas e critérios científicos e técnicos aplicáveis à matéria, tal como estabelecidos por organizações e entidades internacional e nacionalmente reconhecidas; e ii) da observância dos princípios constitucionais da precaução e da prevenção, sob pena de se tornarem corresponsáveis por eventuais violações a direitos.

\footnotetext{
${ }^{7}$ ADI 6421, 6422, 6424, 6425, 6427, 6428 E 643I MC/DF. Rel. Min. Roberto Barroso. Julgado em 20 e 2I/05/2020.
} 
Nessa esteira, sobreveio o seguinte questionamento: a tese fixada pelo STF continua tendo aplicabilidade, em que pese a medida provisória que a originou tenha perdido a validade, sendo aplicável para fins de aferição de responsabilidade dos agentes públicos durante à pandemia?

Destarte, embora a medida provisória tenha sido extirpada do ordenamento jurídico pátrio, não se vislumbra nada que possa concluir que o mesmo tenha ocorrido com a tese fixada pelo STF, porquanto o controle normativo de constitucionalidade qualifica-se como típico processo de caráter objetivo, vocacionado, exclusivamente, à defesa, em tese, da harmonia do sistema constitucional, tendo por função instrumental viabilizar o julgamento da validade abstrata do ato estatal em face da Constituição da República ${ }^{8}$.

Ademais, embora o precedente que será trazido à baila não seja próprio da situação concreta apresentada, acredita-se que esse milita a favor da presunção da aplicabilidade da tese fixada em sede de controle concentrado de constitucionalidade conquanto a medida provisória apreciada tenha perdido a sua validade, tendo em vista que o STF já decidiu anteriormente que não há perda de objeto quando, mesmo sendo a lei impugnada de vigência temporária e já exaurida, a ADI for proposta antes de esgotada a sua vigência.

A esse respeito, colacionamos trechos das ementas confeccionadas do julgamento da $\mathrm{ADI}$ no $3.146 / \mathrm{MG}^{9}$ e $\mathrm{n}^{\mathrm{o}} 4.356 / \mathrm{CE}^{\mathrm{IO}}$ :

(...) Preliminar de prejudicialidade: dispositivo de norma cuja eficácia foi limitada até 31.12.2005. Inclusão em pauta do processo antes do exaurimento da eficácia da norma temporária impugnada. Julgamento posterior ao exaurimento. Circunstâncias do caso afastam a aplicação da jurisprudência do Supremo Tribunal Federal sobre a prejudicialidade da ação, visto que o requerente impugnou a norma em tempo adequado. Conhecimento da ação (...). (ADI 3.146/DF, Rel. Min. Joaquim Barbosa, DJ 19/12/2006)

(...) I. Singularidades do caso afastam, excepcionalmente, a aplicação da jurisprudência do Supremo Tribunal Federal sobre a prejudicialidade da ação, visto que houve impugnação em tempo adequado e a sua inclusão em

\footnotetext{
${ }^{8}$ STF - AG.REG. na ADI 2422 DF, Rel. Min. Celso de Mello, DJE 29/1o/2014.

${ }^{9}$ ADI no 3.146/DF, Rel. Min. Joaquim Barbosa, Tribunal Pleno, julgado em ir/o5/2006.

${ }^{\text {ro }}$ ADI no 4.356/CE, Rel. Min. Dias Toffoli, Tribunal Pleno, julgado em 09/o2/201r.
} 
pauta antes do exaurimento da eficácia da lei temporária impugnada, existindo a possibilidade de haver efeitos em curso (art. $7^{\text {o }}$ da Lei I4.506/2009) (...). (ADI 4.356/CE, Rel. Min. Dias Toffoli, DJ II/o5/20II)

Logo, conclui-se que, se é possível analisar a constitucionalidade de leis impugnadas ainda que sua vigência já tenha se exaurido, com mais razão deve prevalecer vigente e aplicável o entendimento fixado pelo STF em sede de controle concentrado de constitucionalidade, quando da análise de medida provisória que perdeu a sua validade posteriormente ao julgamento.

Quanto ao caráter vinculante da tese fixada, tem-se que a formação de precedentes busca estabilizar a jurisprudência, privilegiando princípios fundamentais como o da segurança jurídica e razoável duração do processo, com vistas a ofertar uma racionalidade normativa para a construção de um modelo de precedentes embasada na pluralidade de litigiosidade e em conformidade com o processo democrático, dotando-a de certa previsibilidade.

Justifica-se ainda como primordial a formação e respeito aos precedentes judiciais, pois de acordo com Alexandre Bahia e Dierle Nunes (2014, pág. 433-471), no cenário atual:

parece haver um fomento do desrespeito da opinião de uma corte, mesmo após a prolação de uma decisão pelo pleno ou corte especial, em prol de um juízo personalista que despreza o passado institucional (integridade) e que acaba alimentando a litigiosidade pela evidente possibilidade de êxito embasada em julgado extraído de nossa jurisprudência lotérica.

Desse modo, ululante a importância do respeito aos precedentes vinculantes, pois o que evidentemente se quer combater é a anarquia interpretativa típica de nosso sistema e que induziu a adoção do presente modelo normativo de precedentes, ora em comento, para que possamos nos aproximar das virtudes, sem copiar os equívocos, de um legítimo direito jurisprudencial. (HUMBERTO, NUNES, BAHIA, PEDRON, pág. 375)

Nesse sentido, o novo CPC de 2015 legitimou os chamados precedentes vinculantes, de aplicação obrigatória pelos Tribunais, os quais abarcam as decisões 
proferidas em controle concentrado de constitucionalidade, sendo, inclusive, cabível Reclamação em caso de sua inobservância. Nessa toada, preconiza o CPC:

Art. 927. Os juízes e os tribunais observarão:

I - as decisões do Supremo Tribunal Federal em controle concentrado de constitucionalidade;

Art. 988. Caberá reclamação da parte interessada ou do Ministério Público para:

III - garantir a observância de enunciado de súmula vinculante e de decisão do Supremo Tribunal Federal em controle concentrado de constitucionalidade;

Assim, resta claro a força das decisões do Supremo Tribunal Federal em controle de constitucionalidade, caracterizando-se como precedentes vinculantes de aplicação obrigatória pelo judiciário, incluindo os próprios Ministros do STF ao decidirem monocraticamente, pois assim preconiza-se o princípio da colegialidade, sendo, não uma decisão do Ministro, mas sim, da Corte Constitucional.

\section{DA ANÁlISE DA DECISÃO MONOCRÁTICA PROFERIDA NA ADPF 70I/MG}

No bojo da APDF no 7or/MG, o Excelentíssimo Ministro Nunes Marques, do STF, decidiu monocraticamente pela concessão de medida liminar determinando que os Estados, Distrito Federal e Municípios se abstenham de editar ou de exigir o cumprimento de decretos ou atos administrativos locais que proíbam completamente a realização de celebrações religiosas presenciais, por motivos ligados à prevenção da Covid-ı9, com a manutenção de protocolos sanitários de prevenção.

Nessa vereda, pincelamos aqueles que consideramos os principais argumentos que consubstanciaram a decisão supramencionada e motivaram o convencimento do juízo, de forma a viabilizar a análise que será realizada:

a) Em preliminar:

(...) Não se ignora que, no julgamento do Agravo Regimental na ADPF 703/BA, Rel. Min. Alexandre de Moraes, julgado em 17/02/2021, este Tribunal considerou que a ora autora não seria parte legítima.

Contudo, este caso possui premissas fáticas distintas, a atrair assim o distinguishing. Com efeito, aqui o provimento buscado pela Associação guarda relação fundamental com seus objetivos essenciais, consistentes na 
proteção da liberdade religiosa. Por prudência, ao menos neste momento processual, esta Suprema Corte deve prestigiar a instrumentalidade do processo, na medida em que o objeto desta ação diz com a proteção da liberdade de culto e religião, garantia constitucional.

Além disso, é certo que, no Agravo Regimental no ADPF 696, Rel. Min. Marco Aurélio, julgado em 30/ri/2020, o Tribunal, ainda que implicitamente, aceitou a legitimidade da Associação Brasileira de Juristas Pela Democracia - ABJD. Assim, na existência de aparente divergência jurisprudencial, deve-se prestigiar a concreção do Acesso à Justiça, conforme art. $5^{\circ}, \mathrm{XXXV}$, Constituição Federal: “(...) a lei não excluirá da apreciação do Poder Judiciário lesão ou ameaça a direito”; (...) (grifo nosso)

b) No mérito:

[...] Ao tratar o serviço religioso como não-essencial, Estados e municípios podem, por via indireta, eliminar os cultos religiosos, suprimindo aspecto absolutamente essencial da religião, que é a realização de reuniões entre os fiéis para a celebração de seus ritos e crenças.

A proibição categórica de cultos não ocorre sequer em estados de defesa (CF, art. 136, § I으, I) ou estado de sítio (CF, art. 139). Como poderia ocorrer por atos administrativos locais? Certo, as questões sanitárias são importantes e devem ser observadas, mas, para tanto, não se pode fazer tábula rasa da Constituição.

Observa-se, nesse sentido, que diversas atividades também essenciais, tais como o serviço de transporte coletivo, vêm sendo desenvolvidas ainda que em contexto pandêmico, demandando para tanto um protocolo sanitário mínimo que, com as devidas considerações, poderia ser também adotado no presente caso.

Entendo por demais gravosa a vedação genérica à atividade religiosa, da forma como prevista em parte dos diplomas objeto da presente ação, traduzindo-se em medida atentatória a preceito fundamental consubstanciado em liberdade religiosa.

Reconheço que o momento é de cautela, ante o contexto pandêmico que vivenciamos. Ainda assim, e justamente por vivermos em momentos tão difíceis, mais se faz necessário reconhecer a essencialidade da atividade religiosa, responsável, entre outras funções, por conferir acolhimento e conforto espiritual. (...)

Com todo o respeito ao Excelentíssimo Ministro, mas nenhum dos argumentos contidos em sua fundamentação é capaz de sustentar minimamente a constitucionalidade da decisão proferida, conforme ver-se-á mais a frente.

\section{3. $\mathrm{Da}$ inconstitucionalidade formal}

Inicialmente, ressalta-se combalido o distinguinshing realizado pelo Ministro, pois este se pautou em um "precedente implícito" (ADPF 696/DF)

\footnotetext{
${ }^{11}$ ADPF no 696/DF, Rel. Min. Marco Aurélio, julgado em 19/o6/2020.
} 
precedente explícito (ADPF 703/BA) ${ }^{12}$, o qual versava justamente acerca da ilegitimidade da Autora da presente ADPF em análise, Associação Nacional de Juristas Evangélicos (ANAJURE).

Dessa forma, a decisão encontra-se totalmente desprovida de fundamentação, considerando que sequer trouxe as razões da distinção ou superação do precedente atual, violando o dever constitucional de fundamentação ${ }^{13}$, padecendo do vício de nulidade, além de afrontar princípios como o da isonomia e o da segurança jurídica.

Outrossim, vale ressaltar que a decisão monocrática que concedeu a medida liminar vem à luz após o próprio Supremo Tribunal Federal, no julgamento da ADI 634I/ $\mathrm{DF}^{14}$, haver decidido pela competência concorrente da União, Estado, Distrito Federal e Município para adoção de medidas de enfrentamento da emergência da saúde pública decorrente do coronavírus, autorizando aos demais Entes, mesmo sem autorização da União, adotar medidas como isolamento, quarentena, exumação, necropsia, cremação e manejo de cadáver e restrição à locomoção interestadual e intermunicipal em rodovias, portos ou aeroportos.

A decisão conferiu ainda interpretação conforme com a Constituição ao artigo

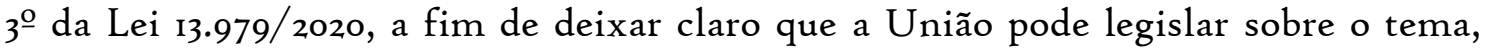
mas que o exercício desta competência deve sempre resguardar a autonomia dos demais entes, uma vez que a possibilidade do chefe do Executivo Federal definir por decreto a essencialidade dos serviços públicos, sem observância da autonomia dos entes locais, afrontaria o princípio da separação dos poderes.

Ora, se o chefe do Poder Executivo não poderia definir por decreto a essencialidade dos serviços públicos sem observar a autonomia dos entes locais, por que razão um Ministro do STF o poderia fazer em decisão monocrática, dispondo sobre a essencialidade da religião e permitindo de cultos e missas presencialmente? É muito poder para pouca (ou nenhuma) responsabilidade.

Esse comportamento inflama ainda mais os ânimos, não se olvidando que o próprio Plenário do STF havia considerado que uma possível usurpação de competência dos Estados e Município pela União configuraria afronta ao princípio da separação dos poderes, inconstitucionalidade material que será tratada mais adiante.

Destarte, o que ocorreu na realidade foi uma anarquia interpretativa por parte de um Ministro do STF, tendo em vista que a sua decisão monocrática violou sistematicamente diversos precedentes da Corte Constitucional conforme exposto acima. Outrossim, pede-se licença para aprofundar um pouco mais com relação à

\footnotetext{
${ }^{12}$ ADPF no 703/BA, Rel. Min. Alexandre de Moraes, julgado em II/II/2020.

${ }^{13}$ CF, Art. 93, inciso IX - todos os julgamentos dos órgãos do Poder Judiciário serão públicos, e fundamentadas todas as decisões, sob pena de nulidade, podendo a lei limitar a presença, em determinados atos, às próprias partes e a seus advogados, ou somente a estes, em casos nos quais a preservação do direito à intimidade do interessado no sigilo não prejudique o interesse público à informação.

${ }^{14}$ ADI no 634I/DF, Rel. Min. Marco Aurélio, julgado em 03/o7/2020.
} 
violação ao precedente firmado na $\mathrm{ADI}$ 6.42I $\mathrm{MC} / \mathrm{DF}$, retomando o que já fora abordado no item 3 deste artigo.

Em apertada síntese, a tese fixada em sede da ADI 6.421 MC/DF fixou parâmetros para a responsabilização dos gestores públicos no âmbito de sua atuação no período da pandemia, preconizando que as medidas de combate ao Covid-ı9 devem ser precedidas de recomendação técnica e fundamentada.

Nessa esteira, no que tange à proteção da saúde e da vida, a jurisprudência do STF se baseia em dois parâmetros: a) as decisões governamentais devem respeitar padrões técnicos e evidências científicas sobre a matéria; b) essas questões se sujeitam ao princípio da prevenção e ao princípio da precaução, ou seja, se existir alguma dúvida quanto aos efeitos de alguma medida, ela não deve ser aplicada. Isso significa que a Administração deve se pautar pela autocontenção. ${ }^{15}$

Nesse contexto, no qual o Brasil já conta com mais de 370.00o,oo (trezentos e setenta mil) mortes decorrentes do covid- $19^{16}$, imprescindível se faz a reunião de esforços de todos os Entes e Poderes, cada qual na sua esfera de atuação e com base em estudos e evidências referendados por organizações e entidades médicas e sanitárias, reconhecidas nacional e internacionalmente, assim como a observância dos princípios constitucionais da precaução e da prevenção, conforme citados alhures.

Desta sorte, sem adentrar ao mérito da essencialidade da atividade religiosa utilizada como fundamento da decisão monocrática do Excelentíssimo Ministro Nunes Marques, advoga-se pela existência de violação ao precedente vinculante constituído na ADI 6.42I $\mathrm{MC} / \mathrm{DF}$, porquanto ao substituir as ações adotadas pelos gestores públicos, a decisão do Ministro deveria estar amparada em fortes evidências técnicas e científicas, o que a priori, não restou configurado no caso concreto, visto que a decisão não se baseou em nenhuma fonte apta a repelir as justificativas das ações adotadas pelos gestores públicos.

Nesse sentido, não possui lógica que os administradores públicos devam se submeter aos parâmetros decisórios fixados pelo Plenário do STF para realizar medidas de combate ao covid-ı9 sob pena de corresponsabilização, e que os membros do Judiciário, quando da supressão de tais medidas, não estejam sujeitos aos mesmos paradigmas, inclusive sob pena de serem responsabilizados. Como diz o dito popular: "pau que dá em Chico dá em Francisco"!

É inconcebível, do ponto de vista do princípio democrático, da separação dos poderes, da colegialidade, que apenas um Ministro do Supremo tenha o condão de permitir a realização de cultos e missas presenciais em todo País, quando nem o Presidente da República o poderia fazer, pois deve respeito ao pacto federativo e a autonomia dos demais entes, como bem asseverou o Plenário do Supremo, e

\footnotetext{
${ }^{15}$ https://www.buscadordizerodireito.com.br/jurisprudencia/detalhes/815104ed949f9deaf $45165 \mathrm{c} 4 \mathrm{~b} 83370$ I3? palavra-chave $=$ covid + responsabiliza $\% \mathrm{C}_{3} \% \mathrm{~A} 7 \% \mathrm{C}_{3} \% \mathrm{~A}_{30} \&$ criterio-pesquisa $=\mathrm{e}$

${ }_{16} \mathrm{https} / /$ gr.globo.com/bemestar/coronavirus/noticia/2021/o4/17/brasil-ultrapassa-371-mil-mortospor-covid-pais-registrou-2865-mortes-em-24-horas.ghtml
} 
tampouco o Poder Legislativo tem a prerrogativa de, por meio de apenas um membro do Congresso Nacional, criar leis que vigorem em todo o território nacional.

Do exposto, restam fortes indícios acerca da inconstitucionalidade formal da decisão monocrática estudada, porquanto viola o dever de observância de diversos precedentes de caráter vinculante formados pelo Guardião da Constituição.

\subsection{Da inconstitucionalidade material}

A saúde é um direito fundamental, de caráter programático e eficácia limitada, eis que além de preconizar uma tarefa, uma finalidade a ser atingida, diferentemente dos direitos fundamentais de defesa que preveem uma abstenção do Estado, esse requer a intervenção do poder legislativo infraconstitucional para que o direito alcance a sua eficácia plena, por meio de prestação positiva por parte do Estado.

De tal sorte, por ser um direito de prestação positiva, demanda o emprego de recursos públicos, influenciando tanto na esfera socioeconômica do Ente Público, quanto na esfera de sua competência, porquanto este é que detém a legitimidade para a implementação das políticas públicas, dentro de sua possibilidade técnica, orçamentária e financeira, caracterizando-se esses fatores como atributos do princípio da reserva do possível, o qual pode vir a representar óbice à realização da plena efetividade da norma constitucional.

Contudo, em que pese o direito a saúde seja considerado norma programática, de eficácia limitada, convém destacar que a doutrina majoritária, quiçá unanime, preleciona que todas as normas constitucionais, são dotadas de um mínimo de eficácia e aplicabilidade, conforme o seu grau de densidade normativa, sendo possível a sua aplicação direta nos limites da sua normatividade, não constituindo as normas de eficácia limitada meros conselhos, advertências e/ou proclamações de cunha ideológico.

A esse respeito, trazemos a lição do Professor Ingo Wolfgang Sarlet (2009, pág. 294), o qual em seu livro a eficácia dos direitos fundamentais, assim apregoa:

Todas as normas de direito fundamentais são dotadas de eficácia e, em certa medida, diretamente aplicáveis já ao nível da Constituição e independentemente de intermediação legislativa. [...] aqui repisamos para espancar toda e qualquer incompreensão para com a nossa posição, todas as normas de direitos fundamentais são diretas (imediatamente) aplicáveis na 
medida de sua eficácia, o que não impede que se possa falar de uma dimensão "programática" dos direitos fundamentais.

Nessa esteira, certo da eficácia mínima dos direitos fundamentais, verifica-se que essa contempla como consequências, dentre outras, a revogação/não recepção de atos normativos anteriores contrários ao direito fundamental positivado e a possibilidade de serem utilizados como parâmetros não só para o controle de constitucionalidade, mas para interpretação, integração e aplicação das normas jurídicas, vinculação ao legislador quanto à concretização dos programas e finalidades estabelecidos, além de possuir a chamada dimensão negativa.

Para Jorge Miranda (1988, p. 219-20), a denominada dimensão negativa dos direitos a prestações, dispõe que:

[...] as normas programáticas, ainda que essencialmente se caracterizem como preceptivas (e não proibitivas), também possuem um sentido complementar negativo (ou proibitivo), visto que, além de vedarem a emissão de atos normativos contrários, próbem a prática de comportamentos que tenham por objetivo impedir a produção dos atos destinados à execução das tarefas, fins ou imposições contidas na norma programática.

Desta sorte, essa dimensão negativa acaba por atribuir às normas programáticas, características do direito fundamental de defesa, no que tange a exigir do Estado uma abstenção de atuar contrariamente ao conteúdo da norma constitucional que prevê direitos fundamentais. Nessa vereda, a doutrina nacional consagra, inclusive, que tal exigência de abstenção representa um direito subjetivo do cidadão. Assim, entendem Meirelles Teixeira, Luís Roberto Barroso e Celso Antônio Bandeira de Mello, os quais reconhecem ao indivíduo o direito de se opor judicialmente ao cumprimento de regras ou à sujeição de atos contrários ao sentido do preceito constitucional que o atingem pessoalmente ${ }^{17}$.

Vale a pena ressaltar que Jorge Miranda (1993, p. 283-4), para além da dimensão negativa, aponta a existência de uma positiva, quanto à vinculação do Poder Judiciário aos direitos fundamentais, o qual tem o dever de atribuir-lhes à

\footnotetext{
${ }^{17}$ Nesse sentido, afirma Ingo Wolfgang Sarlet, em sua obra A Eficácia dos Direitos Fundamentais ıo ${ }^{\text {. }}$. ed., rev., atual. e ampl. Porto Alegre: Livraria do Advogado, 2009, p. 297.
} 
maior eficácia possível perante o sistema jurídico, através da aplicação, interpretação e integração.

Nesse diapasão, a decisão analisada mostra-se materialmente inconstitucional e extremamente temerária, porquanto afronta o direito fundamental à saúde em todas as suas dimensões, na medida em repeliu a atuação de gestores públicos no combate à pandemia quando vedou a restrição de práticas religiosas presenciais em templos e igrejas, de forma que impediu a produção de atos, devidamente fundamentados em evidências técnicas e científicas, destinados a garantir o direito fundamental à saúde e à vida.

Outra inconstitucionalidade material detectada e que vale a pena ressaltar, consiste na afronta a separação dos poderes como assentou o Plenário do STF, quando a maioria dos Ministros aderiram a interpretação conforme ao art. $3^{\circ}$ da Lei no 13.979/2020, proposta pelo Ministro Edson Fachin, que no seu entendimento, a possibilidade do chefe do Executivo Federal definir por decreto a essencialidade dos serviços públicos, sem observância da autonomia dos entes locais, afrontaria o princípio da separação dos poderes ${ }^{\mathrm{I}}$.

Desta feita, ao substituir os membros do Poder Executivo no combate à pandemia, em puro ativismo judicial, o Excelentíssimo Ministro Nunes Marques indubitavelmente fragiliza o processo democrático e viola a separação dos poderes. A respeito da forma como o ativismo judicial vem ocorrendo no Brasil, alerta Elival Ramos (2010, p. 120)

Com efeito, nos Estados democráticos a subversão dos limites impostos à criatividade da jurisprudência, com o esmaecimento de sua função executória, implica deterioração do exercício da função jurisdicional, cuja autonomia é inafastável sob a vigência de um Estado de Direito, afetando se, inexoravelmente, as demais funções estatais, máxime a legiferante, o que, por seu turno, configura gravíssima agressão ao Princípio da Separação dos Poderes

\footnotetext{
${ }^{18}$ http://www.stf.jus.br/portal/cms/verNoticiaDetalhe.asp?idConteudo $=441447 \#: \sim: t e x t=$ No\%2oseu\%2

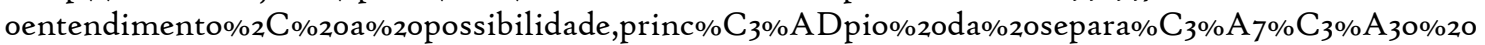
dos\%2opoderes.
} 
De tal modo, defende o autor que o ativismo acarreta instabilidade à harmonia necessária entre o Executivo, Legislativo e o Judiciário, desabona o princípio da separação de poderes e atribui ao juiz um poder criador da norma que é estranho ao modelo de organização do Estado erigido sob a doutrina da separação de poderes. No caso dos Ministros do STF, os dota de poderes quase que ilimitados.

Corrobora a inconstitucionalidade afirmada, a medida cautelar concedida pelo Ministro Presidente Dias Toffoli nos autos da Reclamação no 4 I.935/ $\mathrm{MT}^{19}$, a qual objetivava suspender os efeitos da decisão judicial que havia relaxado as medidas de prevenção e contenção do novo coronavírus em Cuiabá (MT), determinando o aumento da circulação de ônibus e proibindo o governo local de restringir os horários de funcionamento das atividades consideradas essenciais.

Colacionamos trecho da decisão do Ministro:

\begin{abstract}
Note-se que embora a decisão de origem consigne que "os decretos editados nem de longe se enquadram nas Normas Científicas e do Decreto Estadual", o que deixaria "claro que as atividades essenciais foram classificadas de modo aleatório, ao talante do administrador”, não se observa a devida fundamentação quanto ao ponto, ou seja, não parece ter havido a efetiva demonstração do porquê os critérios técnicos adotados pelo estado estariam em posição de maior evidência científica do que os utilizados pelo Município em seu Decreto. Ausente, assim, fundamentação apta a justificar a prevalência de uma norma sobre outra, e ausente ainda indicação de eventual normatização do Município em matéria de competência estadual, considero ser o caso de concessão da tutela pretendida. (grifo nosso)
\end{abstract}

De toda a sorte, entendeu o Ministro Presidente que a decisão do juízo de Io grau (muito semelhante à do Ministro Nunes Marques) divergia do que foi decido pelo STF, ressaltando ainda que a decisão não indicou porque os critérios técnicos adotados pelo estado estariam em posição de maior evidência científica do que os utilizados pelo município para regular o funcionamento das atividades essenciais, considerando-a privada de fundamentação.

Com base no exposto, evidente também a interferência indevida da decisão monocrática apreciada no âmbito do Poder Executivo, eis que não se limitou à análise da legalidade dos atos administrativos que visavam a restrição do

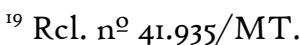


funcionamento dos cultos e missas de modo presencial, mas procedeu a um real exame de mérito, contudo sem considerar o princípio da precaução, o qual restaria materializado pela indicação dos critérios científicos aptos a fundamentar a decisão, em patente ofensa ao princípio da separação dos poderes.

\section{DA POSSIBILIDADE DE RESPONSABILIZAÇÃO DO ESTADO POR ATOS DO JUDICIÁRIO EM TEMPOS DE PANDÊMIA}

A responsabilidade do Estado é prevista na Constituição (art. $37, \S^{\circ}{ }^{\circ}{ }^{20}$, na modalidade objetiva, ou seja, independentemente de dolo ou culpa, sendo possível, no entanto, excludentes de responsabilidade como culpa exclusiva da vítima e caso fortuito e força maior, sendo adotada a chamada Teoria do Risco Administrativo. Ocorre que, no que tange a responsabilidade do Estado em virtude decisões judiciais decorrentes da atuação do Poder Judiciário, existem muitas controvérsias, sendo a regra a irresponsabilidade do Estado por decisões judiciais cíveis ${ }^{2 \mathrm{I}}$.

A esse respeito, o Professor Lucas Rocha Furtado traz razoável entendimento, o qual preleciona que no caso de trânsito em julgado, não cabe a reparação em respeito à coisa julgada; mas no caso de decisões liminares incorretas, concedidas ou não, a indenização é viável.

Destarte, não tem como subsistir essa cultura de irresponsabilidade do Judiciário enquanto Poder Público, que é contrária a ditames como o da transparência, prestação de contas, dentre outros, pois com o avanço e fortalecimento da democracia brasileira, veio junto a ideia do accountability. Destaca Anna Maria Campos (1990) essa relação estreita do accountabilily com a democracia, justificando que não há como se exigir prestação de contas, nem responsabilização, em regimes ditatoriais.

\footnotetext{
${ }^{20}$ CF. Art. 37 \& 6 ㅇ: As pessoas jurídicas de direito público e as de direito privado prestadoras de serviços públicos responderão pelos danos que seus agentes, nessa qualidade causarem a terceiros, assegurado o direito de regresso contra o responsável nos casos de dolo ou culpa”.

${ }^{21}$ No caso de decisões judiciais na seara criminal, é possível a responsabilização do Estado por condenação criminal errônea, contudo o agente público (juiz) só poderá ser regressivamente responsabilizado em casos de dolo ou fraude.
} 
Nas palavras de Luiz Carlos Bresser Pereira (1990, p. 49-96):

sem dúvida um objetivo intermediário fundamental em qualquer regime democrático é aumentar a 'responsabilização' (accountability) dos governantes". E complementa que a governabilidade na democracia depende de (i) existência de instituições políticas que promovam a comunicação entre Estado e sociedade civil; (ii) mecanismos de accountability de políticos e burocratas; (iii) equilíbrio entre demandas da sociedade e atendimento pelo governo; (iv) manutenção de um contrato social básico.

Desse modo, como visto no decorrer deste artigo, irrefutável que o Judiciário, amparado pelo ativismo judicial, muitas vezes se comporta como o próprio governante, decidindo indevidamente acerca de políticas públicas, sem, contudo, estar submetido ao regime de responsabilização dos outros poderes, o que valida a necessidade de se discutir com mais afinco o papel do judiciário, os seus limites e a possibilidade de responsabilização.

Nesse sentido, Raup e Pinho (2014) explicam que a questão da prestação de contas explica apenas parte do conceito de accountability, cujo significado é mais abrangente, envolvendo "responsabilidade (objetiva e subjetiva), controle, transparência, obrigação de prestação de contas, justificativas para as ações que foram ou deixaram de ser empreendidas, premiação e/ou castigo" (RAUP E PINHO, 20I4, p. 145)

Nessa esteira, a nossa construção para o entendimento de que é possível a responsabilização do Estado por atos do Poder Judiciário, partiu de aspectos analisados da decisão monocrática proferida na ADPF no 701 e da premissa do equilíbrio entre os Poderes, aplicando-se analogicamente o entendimento jurisprudencial e doutrinário quanto à responsabilidade do Poder Legislativo, em casos de atos legislativos inconstitucionais, admitida pelo STF:

Ato legislativo. Inconstitucionalidade. Responsabilidade civil do Estado. Cabe responsabilidade civil pelo desempenho inconstitucional da função do legislador" (STF, RE no 158.962, Rel. Min. Celso de Mello, RDA 191/175). No mesmo sentido: STF, RE 153.464, Rel. Min. Sepúlveda Pertence. JSTF 189/14: "O Estado responde civilmente por danos causados aos particulares pelo desempenho inconstitucional da função do legislar. (grifo nosso) 
Ademais, a doutrina majoritária admite ainda a responsabilidade legislativa pela edição das chamadas leis meramente formais ou leis de efeitos concretos. Nesse caso, o ato apenas formalmente se apresenta como lei; na prática, cuida-se de verdadeiro ato administrativo que impõe a pessoas determinadas algum encargo (SCATOLINO; TRINDADE, 2019, p. I009)

Ora vejamos, se da decisão monocrática estudada acabou por substituir as condutas adotadas pelos gestores públicos quanto à restrição a realização de práticas religiosas em templos e igrejas, presume-se que o judiciário, em verdade, culminou realizando um ato administrativo no lugar administrador público (Poder Executivo), estando, contudo, submetido aos mesmos limites fixados anteriormente pelo STF, como pautar as suas decisões em recomendações técnicas e fundamentadas, sob pena de se tornarem corresponsáveis por eventuais violações a direitos.

Outrossim, de igual modo, em sendo admissível a responsabilidade legislativa em casos de atos legislativos inconstitucionais, razoável também admitir-se a responsabilidade judiciária por decisões monocráticas de Ministros do STF tidas por inconstitucionais, assim como outras decisões teratológicas oriundas do Poder Judiciário, flagrantemente violadoras de direitos constitucionais, em função da dimensão positiva ensinada pelo ilustre mestre Lisboa, a qual vincula a atuação dos juízes e tribunais, por meio da aplicação, interpretação e integração, a conferir às normas de direitos fundamentais a maior eficácia possível.

\section{CONCLUSÃO}

Por todo o exposto, em que pese sejam previstas no ordenamento jurídico e extremamente necessárias em casos de urgência, as decisões monocráticas em sede do Supremo Tribunal Federal restaram banalizadas, representando $82 \%$ do total das decisões da Corte Constitucional, enfraquecendo o seu papel enquanto Guardião da Constituição perante à sociedade, de modo que reforça os argumentos de violação ao princípio democrático e à separação dos poderes quando desrespeita à colegialidade da Corte desnecessariamente, refletindo na mitigação de sua independência e 
imparcialidade, características primordiais para que uma instância funcione como Guardião da Constituição.

Destarte, da análise da decisão monocrática proferida na ADPF 7oI/MG, infere-se que está é formalmente inconstitucional, tendo em vista que violou diversos precedentes vinculantes estabelecidos pelo própria Corte Constitucional, em contrariedade ao dever dos tribunais de manter a sua jurisprudência estável, íntegra e coerente.

A esse respeito, deixou de considerar a ilegitimidade ativa da ANAJURE nos termos do ADPF no 703/BA, quando não, ofendeu a obrigatoriedade de fundamentação da decisão imposta aos juízes ao não realizar devidamente o distinguishing do precedente, assim como não observou a decisão do Plenário que reconheceu a competência concorrente de todos os entes para a adoção de medidas de enfrentamento à pandemia, quando interferiu diretamente na autonomia de entes públicos ao impedir a restrição da prática religiosa em cultos e igrejas, em afronta ao princípio da separação dos poderes.

Nesse ponto, constatou-se ainda a inconstitucionalidade material da decisão, violando o direito fundamental à saúde em sua dimensão negativa e positiva, atuando o Ministro quando deveria abster-se de praticar atos que causaram embaraços e dificultaram a busca pela garantia do direito à saúde e à vida, por meio da adoção de medidas de restrição, com vistas a amenizar os efeitos decorrentes da Covid-ı́ e que possui eficácia comprovada pela Organização Mundial da Saúde OMS.

Desta feita, de acordo com os parâmetros fixados pelo STF em sede de controle de constitucionalidade da $M P$ no 966/2020, é possível afirmar que o Ministro incorreu em erro grosseiro, porquanto ao substituir os gestores públicos em suas ações, não fundamentou a sua decisão com base em normas e critérios científicos e técnicos, assim como não observou os princípios constitucionais da prevenção e precaução, tanto que revogou a liminar concedida para se adequar ao entendimento posteriormente fixado pelo STF em sentido contrário ao que havia 
decidido o Ministro, no entanto, era ululante a inconstitucionalidade, não havia necessidade do Plenário afirmar o óbvio.

Observou-se ainda a inconstitucionalidade material devido à violação do princípio da separação dos poderes à luz do entendimento fixado pelo Supremo Tribunal Federal na ADI no 634I/DF, considerando que decisão monocrática adentrou no mérito das ações adotadas pelos gestores públicos no combate ao covid19, em que pese o STF tenha atribuído competência concorrente a todos os entes, ressaltando expressamente que o desrespeito a autonomia de quaisquer dos Estados, DF e Municípios representaria afronta ao princípio da separação dos poderes.

Dessarte, no campo da possibilidade de responsabilização do Judiciário, ressalta-se que a jurisprudência atual e a doutrina caminham para a mitigação da regra que prevê a irresponsabilidade do Estado por decisões judiciais, tendo em vista que está em dissonância com os preceitos vitais da democracia.

Como dito alhures, se é possível a responsabilização do Estado pelo desempenho inconstitucional da função de legislar e em decorrência de leis de efeitos concretos, não se vislumbra óbice para que seja possível a responsabilização do judiciário por decisões judiciais precárias reputadas flagrantemente inconstitucionais, que porventura violem direitos fundamentais, em quaisquer de suas dimensões, negativas e positivas.

Assim, no atual contexto pandêmico, levando-se em consideração que o Supremo Tribunal Federal já consolidou entendimento acerca dos requisitos a serem observados pelos agentes públicos quando da adoção de medidas de enfrentamento ao Covid-ı, sob pena de se tornarem corresponsáveis por eventuais violações a direitos, plausível à possibilidade da corresponsabilização de membros do judiciário, enquanto agentes públicos, quando atuarem fora dos limites da judicatura, em afronta ao princípio da separação dos poderes.

\section{REFERÊNCIAS BIBLIOGRÁFICAS}

DWORKIN. Ronald. Levando os direitos a sério. Tradução de Nelson Boeira. São Paulo: Martins Fontes, 2002, p. 132. 
BARROSO, Luís Roberto. A razão sem voto: o Supremo Tribunal Federal e o governo da maioria. Revista Brasileira de Políticas Públicas, Brasília, v. 5, n. especial, 2015, p. 27.

BOBBIO, Norberto. Teoria Geral da Política. A filosofia Política e as lições dos clássicos. Rio de Janeiro: Campus, 2000, p. 380.

BOBBIO, Norberto. O futuro da democracia: uma defesa das regras do jogo. II $^{\underline{a}}$ ed. São Paulo: Paz e Terra, 2009, p. 30-32.

PEREIRA, L.C.B. A reforma do Estado dos anos 9o: lógica e mecanismos de controle. Lua Nova, v. 45, p. 49-96, 1998.

CAMPOS, A.M. Accountability: quando poderemos traduzi-la para o português? Revista de Administração Pública, Rio de Janeiro, fev./abr. 1990.

COHENDET, Marie-Anne, La collégialité des jurisdicions: um príncipe em voie de disparition?. In Revue Française de droit constitutionnel, no 68, outubro de 2006. Ed. PUF, Paris, p. $713 / 736$.

SCHMITT, Carl. O guardião da Constituição. Trad. Geraldo de Carvalho. Belo Horizonte: Del Rey, 2007, p. 176-177

MIRANDA, Jorge. Manual de direito constitucional. Volume II. 2. ed. Coimbra: Coimbra Editora, 1988, p. 219-20.

Manual de direito constitucional. Volume IV. 2. ed. Coimbra: Coimbra Editora, 1993, p. 283-4.

MARINONI, Luiz Guilherme. Precedentes obrigatórios. 3. ed. São Paulo: Revista dos Tribunais, 2013. p. 64.

FURTADO, Lucas Rocha. Curso de Direito Administrativo. Belo Horizonte: Fórum, 2007.

HUMBERTO, Theodoro Júnior; NUNES, Dierle; BAHIA, Alexandre Franco; PEDRON, Flávio Quinaud. Novo CPC - Fundamentos e sistematização. $3^{\circ}$ Ed, Rev., atual. e ampl. - Rio de Janeiro: Forense, 2016, p. 375

NUNES, Dierle; BAHIA, Alexandre. "Jurisprudência Instável" e seus riscos: a aposta nos precedentes vs. Uma compreensão constitucionalmente adequada do seu uso no Brasil. In: MENDES, Aluisio Gonçalvez de Castro; MARINONI, Luiz Guilherme; WANBIER, Teresa Arruda Alvim (orgs.). Direito Jurisprudencial. São Paulo: RT, 2014, v. II, p. 433-47I.

RAMOS, Elival da Silva. Ativismo Judicial: Parâmetros dogmáticos. São Paulo: Saraiva, 2010, p. ז20. 
RAUPP, Fabiano Maury; PINHO, José Antônio Gomes de. Prestação de contas nos portais eletrônicos de Assembleias Legislativas: um estudo após a Lei de Acesso à informação. Revista Gestão e Planejamento. v. I5, n. I, jan./abr. 2014, p. I44-16r.

SARLET, Ingo Wolfgang. A eficácia dos direitos fundamentais. Io ${ }^{\mathrm{a}}$. ed., rev., atual. e ampl. Porto Alegre: Livraria do Advogado, 2009, p. 294.

SCATOLINO, Gustavo; TRINDADE, João. Manual didático de direito administrativo. $7^{\underline{a}}$ ed. Ver., ampl. E atual. - Salvador: Ed. JusPodivm, 2019, p. 1oo9.

POGREBINSCHI, Thamy. Ativismo Judicial e Direito: Considerações sobre o Debate Contemporâneo. Revista Direito, Estado e Sociedade, no ${ }_{17}$, agosto-dezembro de 2000 , pág. 2.

CAVALCANTE, Márcio André Lopes. Análise da constitucionalidade da MP 966/2020, que dispõe sobre a responsabilização de agentes públicos por atos relacionados com a pandemia da covid-I9. Buscador Dizer o Direito, Manaus. Disponível em: 〈https://www.buscadordizerodireito.com.br/jurisprudencia/detalhes/815104ed949f9 deaf45165c4b8337013>. Acesso em: 19/04/2021

BRASIL. Supremo Tribunal Federal. Ação Direta de Inconstitucionalidade $\mathrm{n}^{\mathrm{o}}$ 4.356/CE - Distrito Federal. Relator Min. Dias Toffoli. Julgada em o9/o2/201I. Disponível em: <https://stf.jusbrasil.com.br/jurisprudencia/19735377/acao-direta-deinconstitucionalidade-adi-4356-ce>. Acesso em: 17/04/2021.

BRASIL. Supremo Tribunal Federal. Ação Direta de Inconstitucionalidade $\mathrm{n}$ o 3.146/DF - Distrito Federal. Relator Min. Joaquim Barbosa. Julgada em 09/02/2011. Disponível em: $<$ https://stf.jusbrasil.com.br/jurisprudencia/I4732484/acao-direta-deinconstitucionalidade-adi-3146-df $>$. Acesso em: 17/04/202I.

BRASIL. Supremo Tribunal Federal. Ação Direta de Inconstitucionalidade $\mathrm{n}^{\mathrm{o}}$ 6.34I/DF - Distrito Federal. Relator Min. Min. Marco Aurélio. Julgada em $03 / 07 / 2020$. Disponível

em: <https://stf.jusbrasil.com.br/jurisprudencia/882665736/acao-direta-deinconstitucionalidade-adi-634I-df-distrito-federal-oo88693-70202010000oo>. Acesso em: 17/04/202I.

BRASIL. Supremo Tribunal Federal. Arguição de Descumprimento de Preceito Fundamental no 703/BA - Distrito Federal. Relator Min. Min. Alexandre de Moraes. Julgado em II/II/2020. Disponível em: <https://stf.jusbrasil.com.br/jurisprudencia/I124668418/arguicao-dedescumprimento-de-preceito-fundamental-adpf-703-ac-0o96437192020100000o/inteiro-teor-I124668425>. Acesso em: 17/04/2021.

BRASIL. Supremo Tribunal Federal. Arguição de Descumprimento de Preceito Fundamental no 696/DF - Distrito Federal. Relator Min. Marco Aurélio. Julgado em 19/06/2020.

Disponível em: 
<https://stf.jusbrasil.com.br/jurisprudencia/ı106712603/arguicao-dedescumprimento-de-preceito-fundamental-adpf-696-df-oog5736582020100000o/inteiro-teor-1106712617>. Acesso em: 17/04/2021.

BRASIL. Supremo Tribunal Federal. Ação Direta de Inconstitucionalidade no 642I/DF - Distrito Federal. Relator Min. Roberto Barroso. Julgado em 20 e 21/o5/2020. Informativo 978. Disponível em: 〈http://www.stf.jus.br/arquivo/informativo/documento/informativo978.htm〉. Acesso em: 18/04/2021.

BRASIL. Senado Federal. Proposta de Emenda à Constituição no 8/2021. Distrito Federal. Disponível em: < https://legis.senado.leg.br/sdleggetter $/$ documento? $\mathrm{dm}=81 \mathrm{I} 8687 \& \mathrm{ts}=\mathrm{I} 61860412226 \mathrm{I} \&$ disposition $=$ inline $>$. Acesso em: 19/04/2021.

BRASIL. Supremo Tribunal Federal. Reclamação no 4I.935/MT - Distrito Federal. Relator Min. Gilmar Mendes. Disponível em: http://portal.stf.jus.br/processos/downloadPeca.asp?id=15343890787\&ext=.pdf. Acesso em 21/o4/202I. 